\title{
Peron's Cultural Influence
}

\section{ANDREW KING \\ QUEENSLAND UNIVERSITY OF TECHNOLOGY}

\author{
Matthew Karush and Oscar Chamosa (eds) \\ The New Cultural History of Peronism: Power and Identity in Mid-Twentieth- \\ Century Argentina \\ Duke University Press, Durham \& London, 2010 \\ ISBN 9780822347385 \\ RRP US\$24.95 (pb)
}

From a cultural studies perspective, culturally engaged accounts of political histories are hard to come by. A few recent Australian publications provide interesting reading, from The Latham Diaries, to the auto- and biographical accounts of our last two prime ministers, but these books inevitably focus on the people and personalities behind the power, rather than the cultural issues at work. ${ }^{1}$ And there is good reason why this is so, given how very few political leaders have become so influential that their impact on a nation's history deserves to be studied as cultural phenomena. But Argentina's Juan Peron is one such leader, whose cultural influence and legacy is examined in Karush and Chamosa's book The New Cultural History of Peronism.

Unlike other books about this controversial leader, Karush and Chamosa's collection of essays focus on the cultural milieu of the first Peron government 
(1946-55), and the lasting political changes which ensued. Peron oversaw the rapid industrialisation of Argentine society during the mid twentieth century, modernising the nation's power and transport infrastructures and, most importantly, developing social services and redirecting profits to the poor. The socialist and protectionist elements of the Peronista ideology are subject to continuing popular debate in Argentina, while the leader's personal life and marriage to the iconic Eva Duarte captures much interest from overseas scholars and journalists. For better or worse, Juan Peron was-and continues to be-a massively popular figure in Argentine history. Karush and Chamosa's book explores this important element of Peron's governance, focusing on the interactions between 'ordinary Argentines and the regime'.

The most innovative part of this project, for me, were the analyses of a range of cultural texts, such as folk and tango music, beauty contests and television melodramas. Without much of a background in Latin American history, it was informing to read about the relationship between the emerging creative industries of the day, such as film, television, magazines and even modernist architectural design, and the regime's style of governance, public relations and speech writing. The authors situate this approach to popular culture within a growing body of literature from Latin American studies, highlighting the work of Daniel James in particular, whose 'bottom-up' (7) analysis of Peronist workers highlights the grassroots influence different social groups had upon the regime's social outlook.

This perspective is captured in Karush's opening article, which looks at how Peron's rhetoric and communication styles were appropriated from the mass culture of the 1930s. Karush shows how popular melodramas, tango lyrics and radio programs provided powerful narratives of social mobility for working-class Argentines. Peron capitalised upon these narratives in his metaphors of nationbuilding and use of working class vernacular in public speeches. Peron's popularity is examined in relation to working class styles of dress and manners in the following chapter, which again draws attention to how Argentina's political divisions were being fought over cultural codes and symbols in the popular domain.

These essays retain a critical distance from Peronist ideologies, showing how broader notions of Argentine identity were already being defined decades earlier in contrast to overseas cultural trends. American jazz music and Hollywood movies 
competed against local tango and television melodramas, for instance, while formalised modes of dress and comportment were derisively associated with the old world of Europe in popular iconography. This writing suggests that Peronism developed as an early cultural reaction to globalisation, as it cleverly harnessed nationalist ideologies through existing media to gain the support of Argentina's working classes. Overseas cultural influences, so the authors suggest, were increasingly being used to counter-define an embattled and morally superior working-class culture of Peron's making in the 1940s.

Elements of working class culture are examined extensively, including the figure of the descamisodos - 'the shirtless' workers of the famous 1945 rally, who would later form the base of Peron's enduring popularity. There are plenty of case studies which illustrate that shabby or tattered dress signified the 'poverty and marginalisation' of workers in the pre-Peronist era. (65) It was the task of Peron's propaganda machine to change this cultural symbolism, and uphold the descamisodos as a more dignified figure within national narratives of liberation and progress. Over time, such popular images of working culture became hackneyed and stereotyped in official publications, but to the Argentine citizens studied in the book, it's clear that they still evoke strong feelings of political empowerment. Drawing upon Raymond Williams's 'structure of feeling' sentiment in a number of chapters, the book places much importance upon these experiential and emotional elements of Peronism.

As interesting as these cultural descriptions are, the privileging of emotional recollection seems to prevent the book from proper engagement with some key cultural terms. There is little interrogation of phrases like 'working class' and 'solidarity', for example, from any popular, cultural or even sociological perspective. And although class and racial 'stereotypes' may have been more prevalent in 1940s' popular culture, the book tends to present such categories as being self-evident. Though there is a brief discussion of how Peron's governance differed from other dictatorial countries elsewhere, particularly the fascist and communist regimes in Europe, the book left me wondering how notions of a collective identity were viewed by particular workers themselves. In the end I was quite forgiving about how these terms were used, not knowing how much they were part of Argentine 
vernacular (given the strong Marxist traditions in Latin American politics), or a reflection of the editors' own critical perspectives.

The editors of this collection of essays from Spanish-speaking academics, should be congratulated for introducing new perspectives of Argentine political culture to Anglophone readers. The book explores interesting material regarding issues of gender and ethnic representation. The Lobato, Damilakou and Torna essay, for instance, describes the impact of the first May Day beauty pageants of the 1940s. This chapter draws upon interviews with former beauty queens to show how, although winners almost always conformed to traditional notions of 'fair-skinned' beauty, their popularity introduced the public to a new 'image of dignified labor' for women. (175) This history of popular representations of sexuality is tied to an equally compelling one of working-class culture, showing how aspects of sexualised femineity were popularised and patronised by political leaders. The article by Lenton, by contrast, looks at the construction of indigenous identity in Argentine politics, critiquing the famous 'Caravan of Peace' of 1946, which initiated a number of important social rights for Indigenous people from the Peron government.

The New Cultural History of Peronism is indeed a useful resource for those interested in Latin American history, offering plenty of themes for undergraduate students to explore. Anglophone readers seeking an entry into the subject may need to do a bit more background work to make the most of this book. Rather than providing a review of past Marxist authors writing about the subject, for instance, the introduction may have been better utilised to acquaint readers with some of the key historical details about Argentina, particularly the class of migrants from Europe who were derided for their wealth and power by Peronist ideology. Essays in the latter half of the book, likewise, were disappointingly missing translations of quoted songs, poems and speeches. While it wasn't hard to track down qualified Spanish translators, I couldn't help but feel that a little extra effort in this respect may have helped broaden the book's appeal to its audience of English-speaking scholars.

For those researchers working on cultural histories in other countries, The New Cultural History of Peronism provides a rich cross-section of case studies to parallel and contrast. While it is an invaluable resource for more specialist researchers of Latin American history and politics, I believe its focus on the cultural 
aspects of governance is an approach that would be welcomed by cultural studies scholars studying political formations in other national contexts.

Andrew King is a tutor and researcher at Queensland University of Technology. His research explores how intercultural relationships are negotiated through commercial media, with a particular interest in mainstream images of Indigenous people.

一NOTES

${ }^{1}$ M. Latham, The Latham Diaries, Melbourne University Press, Melbourne, 2006; J. Howard, Lazarus Rising: A Personal and Political Autobiography, Harper Collins, Sydney, 2010; R. Maklin, Kevin Rudd: The Biography, Penguin, Melbourne, 2008; and N. Stuart, Kevin Rudd: An Unauthorised Political Biography, Penguin, Melbourne, 2007. 